\title{
Labor Migration and Impact of Remittances on Poverty and Income Inequality: Evidence from Estate Sector of Sri Lanka
}

\author{
R.A.P.I.S. Dharmadasa*, J. Weerahewa ${ }^{1}$ and P.A.Samarathunga ${ }^{1}$ \\ Postgraduate Institute of Agriculture \\ University of Peradeniya \\ Sri Lanka
}

\begin{abstract}
There is a continuing debate over the impacts of migration on the developing nations despite the ever-increasing size of internal and international remittances. Moreover, a little attention has been paid to analyze the impact of these financial transfers on poverty and inequality of those countries. This study, using a nationally representative sample, assessed the impacts of migration and remittances on poverty and inequality of estate sector households of Sri Lanka. A multinomial logit-ordinary least squares two-stage selection control model and a simulation analysis were used to estimate the impact of migration and remittances on poverty and inequality. Results reveal that internal and international remittances reduce poverty incidence by $2.14 \%$ and $2.32 \%$, depth of poverty by $1.33 \%$ and $0.98 \%$, and severity of poverty by $0.63 \%$ and $0.48 \%$, respectively. Results further suggest that income inequality slightly decreased due to internal and international remittances. Moreover, the findings support a growing view in the literature that migration is a livelihood strategy and it helps in alleviating poverty.
\end{abstract}

Keywords: Estate sector, inequality, migration, poverty, remittances

\section{INTRODUCTION}

Migration and remittances play a significant role in developing economies by enhancing social wellbeing of those nations. In some countries, contribution by remittances to Gross Domestic Product (GDP) is more than 40\% (World Bank, 2015) and remittances even exceed Foreign Direct Investment (Ratha, 2003; Yang, 2011). At a micro level, remittances play a crucial role in financial dynamics of rural households and have proved to help reduce poverty, relax credit constraints and improve living standard of rural households of developing nations. Since remittances from migrants are recognized as one of the major contributors to the overall household income (Mendola, 2005) and subsequently the development (Mendola, 2012), poverty and income distribution changes within and among household communities.

Among the developing economies, Sri Lanka has also maintained a significant position as one of the migrant-sending countries since 1980 and currently over a million of Sri Lankan migrants work in Persian Gulf Region and Middle East countries. As their migration status, especially in Middle East countries, is temporary, a large portion of migrants' earnings is sent as remittances while they stay, or they bring their earnings when they return. However, the

1 Department of Agricultural Economics and Business Management, Faculty of Agriculture, University of Peradeniya and School of Agriculture and Food, Faculty of Veterinary and Agricultural Sciences, University of Melbourne, Australia

* Corresponding author: sampath@uwu.ac.lk 
cost of migration is high and they may use their earnings to pay their debt and loans during the initial period of migration. Therefore, the immediate impact of remittances on household development may not be seen. Although the case is such in international migration, the case of internal migration is totally different. Most people migrate internally to nearby cities, other major cities and capital city. Some migrate permanently and some migrate temporarily depending on the nature of their employment, family ties, etc. (Dharmadasa, 2011). Most of the internal migrants are young males although most of the international migrants to the Middle East and the Persian Gulf regions are females. According to the World Bank (2007), the most of internal migrants work in garment factories while some are engaged in ad hoc jobs in cities. As far as they send remittances to their families, it could be assumed that remittances should have a significant impact on poverty reduction and income distribution of the households.

Apart from international migration and rural-urban migration, estate ${ }^{2}$ urban migration could also be seen in Sri Lanka. Being the households in the poorest sector [the poverty headcount ratio is 8.8\% according to the Anon. (2018)] in Sri Lanka, people in the estate sector started to diversify their income portfolio by incorporating non-farm income sources. Thus, migration and remittances have become an important source to diversify the income. However, a relatively little attention has been paid to studying the effect of migration and remittances on development aspects of estate households in Sri Lanka. For example, the World Bank (2007) in their report on Sri Lanka Poverty Assessment emphasized the importance of migration on poverty reduction. However, the report further highlighted that the impact of migration could be measured exactly if counterfactual scenario of what household income would have been if one of the household members did not migrate. None of the studies carried out in Sri Lanka in relation to migration and remittance has taken this aspect into account although it is highly important to quantify and measure the impact of migration and remittances on poverty and inequality.

In Sri Lanka, similar to the other developing countries, the majority of people living in rural areas where agriculture has been the main source of income of households for many decades. As a result, incomes in rural areas tend to be lower than the income earned in the urban sector (Adams, 1989). It is this disparity that causes rural people to go elsewhere in the country or outside the country in search of better opportunities with higher salaries (World Bank, 2007). International migration from Sri Lanka (temporary or permanent) occurs to Middle East (ME) countries, Korea, Cyprus, Italy, USA, Canada, Australia and New Zealand (Arunathilake et al., 2010). Most of the international migrants to ME countries are housemaids (60\%) and unskilled labourers (Arunathilake et al., 2010).

This nature of migration is strongly related to poverty and accounts for $66 \%$ of the total number of migrant workers (ADB, 2011). Most housemaids are rural and unskilled, and prior to migration, they are either below the poverty line or just above it (Shaw, 2008). The movement of people from rural areas to the urban growth centre of Colombo has complex and profound effects on poverty and inequality (World Bank, 2007). Perera (2005) discloses that improved levels of income earnings, improved working condition and housing, better services and opportunities for labour participation are consequences of internal migration. In most cases, the estate sector migrants are young people and young labour migration increases the urbanrural gap accelerating the income inequality (Karunaratne, 2008). In a study carried out by Portes (2009) observed that there is a positive effect of remittances on the income of the first decile in Sri Lanka. The author further pointed out that all else equal, remittances not only

\footnotetext{
${ }^{2}$ There are three commonly known sectors viz urban, rural and estate. Estate sector consists of all plantations which are 20 acres or more in extent and ten or more resident laborers.
} 
reduce poverty but also reduce inequality since the income of the bottom of the distribution increases while the income at the top declines, particularly in low-income countries.

The poverty level of estate households may reduce by increasing household income from remittances as most of the remittances are monetary transfers. However, the level of impact on each household can be varied depending on the source and amount of remittances, type of employment as working outside the estate does not necessarily imply higher earnings (World Bank 2007). Therefore, this study attempts to find the impact of remittances on poverty and income inequality of the estate sector of Sri Lanka.

\section{METHODOLOGY}

The main objective of the study was to determine the impact of labour migration on poverty and income inequality of the estate sector of Sri Lanka. To achieve this objective, we need to consider counterfactual income estimates. The counterfactual in this regard could be defined as what the migrant household income would be if the household were not participating in migration receiving remittances. In developing the counterfactual scenarios of what household income (expenditure) and subsequently the poverty and the inequality would have been in the absence of migration and remittances, using we can estimate a mean regression from the households with no migration and remittances and then apply the estimated parameters for the remittances receiving households.

In estimating the regression model we can simply use the ordinary least squares (OLS) method if the households who receive remittances from migrants are not systematically different from non-remittances receiving households. However, throughout the migration literature, most researchers have pointed out the problem of self-selection due to non-randomness of the migrant and remittance receiving subsample of households. As a result of this, we cannot simply estimate an OLS regression model. If we do so, it will generate biased results. On the other hand, there are unobservable characteristics of migrant and remittance-receiving households. If we do not take these into account when estimating a model of migration and remittances, it will generate biased results. To address this issue we used multinomial logitOLS two-stage selection control model

Choosing the multinomial logit-OLS two-stage selection control model has its own advantages. First, it allows us to model multiple choices of migration decision. Second, it allows us to attribute a selection bias in the estimation of earnings to the allocation of individuals with better or worse unobserved characteristics of migration while it links the selection bias to the allocation of individuals to each other alternative ( $\mathrm{Wu}, 2008)$. In estimating counterfactual income, three steps were adopted namely: (1) Parameters predicting per capita household expenditure (excluding remittances) were estimated from all the households that do not receive remittances, (2) Parameters predicted from households with no remittances were applied to households that receive internal remittances from Sri Lanka, and (3) Parameters predicted from households with no remittances were applied to households that receive international remittances. 
Table 1. Description of Variables

\begin{tabular}{|c|c|}
\hline \multicolumn{2}{|c|}{ Household Characteristics } \\
\hline AGEHHH & Age of household head in years \\
\hline GNDRHHH & Gender of Household Head (dummy where $1=$ male, $0=$ otherwise) \\
\hline EDUHHH & Educational Level of Household Head in years \\
\hline HHSZ & Household Size \\
\hline MALES15 & Number of Males over age 15 \\
\hline FEMALES15 & Number of Females over age 15 \\
\hline CHILD6 & Number of Children under age 6 \\
\hline YNGDPNDT & Number of Young Dependents \\
\hline OLDDPNDT & Number of Old Dependents \\
\hline WRKS15 & Number of Workers over age 15 \\
\hline MAXEDU & Maximum Education Level of the Household in years \\
\hline \multicolumn{2}{|c|}{ Human Capital Characteristics } \\
\hline EDU12_ABV & Number of Members over age 15 with 12 years and above education \\
\hline EDU6_11 & Number of Members over age 15 with 6-11 years of education \\
\hline EDU1_5 & Number of Members over age 15 with 1-5 years of education \\
\hline \multicolumn{2}{|l|}{ Networks } \\
\hline ETHNCTY & $\begin{array}{l}\begin{array}{l}\text { Ethnicity of the Household Head (dummy where } 1=\text { Tamil, } \\
0=\text { otherwise) }\end{array} \\
\end{array}$ \\
\hline \multicolumn{2}{|r|}{ 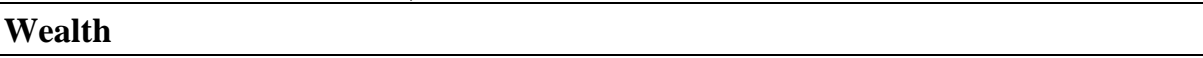 } \\
\hline LIVSTOK & Livestock Owner (dummy where $1=$ yes, $0=$ otherwise) \\
\hline AGRI & Agricultural Land Owner (dummy where $1=$ yes, $0=$ otherwise) \\
\hline HOUSING & $\begin{array}{l}\text { Housing Structure (dummy where } 1=\text { Living in line rooms }{ }^{3} \text {, } \\
0=\text { otherwise ) }\end{array}$ \\
\hline DURABLE & Percentage of Durable Assets owned \\
\hline
\end{tabular}

In estimating income (expenditure) functions, first the multinomial logistic regression was estimated and selection correction terms (mills - Inverse Mills Ratios) were generated from multinomial logit estimates. By applying selection correction terms in income equations, four income functions for households receiving internal remittances and international remittances were estimated with and without Inverse Mills Ratios to check the self-selection bias. Depending on these results, our equation of interest to find the counterfactual income was estimated. Once the counterfactual incomes were estimated, poverty and inequality indices were estimated in including and excluding scenarios of remittances.

\footnotetext{
${ }^{3}$ Line rooms are type of worker houses that have been built in a row.
} 


\section{RESULTS AND DISCUSSION}

\section{Determinants of remittances: estimates of multinomial logit model}

Table 2 presents the regression coefficients of the estimated multinomial logit model. The standard deviations are in the parenthesis. According to the estimates, the overall model is significant at $99 \%$ significance level and the pseudo $\mathrm{R}^{2}$ is 0.16 .

Findings presented in Table 2 show that all the variables related to education are showing positive signs indicating that migration and receipt of remittances increase with the education level of the household members. Further, if the education levels are considered separately, it can be seen that households with members having education levels of advanced level and higher receive more remittances from international migrants while households with members having $6-11$ years of education receive more remittances from internal migrants. It is evident from the results that more members of the households have education levels between 0 and 5 years of schooling. The results also indicate a positive relationship with this predictor. This finding implies that households with members having 0-5 years of education receive more remittances irrespective of whether the household is an internal remittance receiving household or international remittance receiving household. It is also noted in the migration literature that education levels of migrants and other household members positively influence the decision to migrate and send remittances (Adams, 1989; Larson and Mundlak, 1997; Mora and Taylor, 2006 and Matsumoto et al., 2006). Almost all the authors stress that propensity to migrate increases with higher education levels while educational level of household heads (Lewin et al., 2012) significantly influence the migration decision. The results of this study indicate that there is a negative association of distance variable with the migration and receiving remittances. According to Table 2, the time taken to travel to the nearest bus halt is a significant determinant in international migration decision and the sign for the estimated coefficient is negative. Hence, the results suggest that migration and receipt of remittances decrease with the increase in distance to nearest bus halt. As can be observed in estates, they are mostly marginalized areas in Sri Lanka. Until recently, the infrastructure facilities and roads in areas with estates were in poor condition. Sometimes, a bus halt may be reached only after waking a long distance from the households. Therefore, their mobility has been restricted. The estate households may have to come to the nearest city to get their documentary work done if they intend to migrate internationally. To capture this, the time taken to travel to divisional secretariat was used as a proxy. The expected sign for this should also be negative as the more time taken to travel, less will be the propensity to travel. Proving this argument, the results show that migration and receiving remittances will be lower if the distance to divisional secretariat is higher.

In the case of time taken to travel to meet Grama Niladari in the estate, the sign resulted in the model is positive indicating that the more time takes to travel to meet Grama Niladari, the more will be the propensity to migrate and receiving remittances. 
Table 2. Results of Multinomial Logistic Model

\begin{tabular}{|c|c|c|}
\hline Variable & $\begin{array}{l}\text { Receive Internal } \\
\text { Remittances } \\
\end{array}$ & $\begin{array}{c}\text { Receive International } \\
\text { Remittances }\end{array}$ \\
\hline \multicolumn{3}{|l|}{ Household Characteristics } \\
\hline Age of Household head & $0.02(0.38)$ & $-0.05(-0.56)$ \\
\hline Squared Age of Household Head & $-0.00(-0.52)$ & $0.00(0.34)$ \\
\hline Gender of Household Head & $0.14(0.41)$ & $-0.07(-0.13)$ \\
\hline Educational Level of Household Head & $-0.03(-1.27)$ & $-0.04(-1.12)$ \\
\hline Household Size & $-0.46(-1.32)$ & $-0.36(-0.73)$ \\
\hline Number of Males over age 15 & $-0.55(-1.07)$ & $-0.05(-0.07)$ \\
\hline Number of Females over age 15 & $0.25(0.51)$ & $-1.06(-1.42)$ \\
\hline Number of Children under age 6 & $0.03(0.13)$ & $0.09(0.32)$ \\
\hline Number of Young Dependents & $0.36(0.96)$ & $0.81(1.57)$ \\
\hline Number of Old Dependents & $-.02(-0.05)$ & $-0.38(-0.73)$ \\
\hline Number of Workers over age 15 & $-0.70 * * *(-3.84)$ & $-0.44 *(-1.78)$ \\
\hline $\begin{array}{l}\text { Maximum Education Level of the } \\
\text { Household }\end{array}$ & $-0.04(-0.84)$ & $-0.048(-0.79)$ \\
\hline \multicolumn{3}{|l|}{ Human Capital Characteristics } \\
\hline $\begin{array}{l}\text { Number of Members over age } 15 \text { with } \\
12 \text { years and above Education }\end{array}$ & $0.35(1.21)$ & $0.72 *(1.72)$ \\
\hline $\begin{array}{l}\text { Number of Members over age } 15 \text { with } \\
6 \text { - } 11 \text { years of Education }\end{array}$ & $0.79 *(1.79)$ & $0.94(1.48)$ \\
\hline $\begin{array}{l}\text { Number of Members over age } 15 \text { with } \\
0-5 \text { years of Education }\end{array}$ & $0.96 * *(2.05)$ & $1.35 * *(2.01)$ \\
\hline \multicolumn{3}{|l|}{ Networks } \\
\hline Ethnicity & $0.23(0.52)$ & $0.30(0.49)$ \\
\hline \multicolumn{3}{|l|}{ Wealth } \\
\hline Livestock Owner & $-0.48(-1.48)$ & $-0.28(-0.64)$ \\
\hline Agricultural Land Owner & $-0.33(-1.10)$ & $-0.78 *(-1.73)$ \\
\hline Housing Structure & $-0.09(-0.30)$ & $-0.67(-1.58)$ \\
\hline Percentage of Durable Assets owned & $-0.01(-0.08)$ & $0.04 * *(2.02)$ \\
\hline \multicolumn{3}{|l|}{ Distance } \\
\hline $\begin{array}{l}\text { Time taken to travel to the nearest bus } \\
\text { halt }\end{array}$ & $-0.01(-1.17)$ & $-0.08 * * *(-3.90)$ \\
\hline $\begin{array}{l}\text { Time taken to travel to Divisional } \\
\text { Secretariat Office }\end{array}$ & $-0.07 * *(-2.05)$ & $-0.01 *(-1.81)$ \\
\hline $\begin{array}{l}\text { Time taken to travel to Grama } \\
\text { Niladari Office }\end{array}$ & $0.01(0.24)$ & $0.04 * * *(3.23)$ \\
\hline Constant & $0.06(0.04)$ & $0.68(0.29)$ \\
\hline Log likelihood & \multicolumn{2}{|r|}{-294.06} \\
\hline Chi-square (46) & \multicolumn{2}{|r|}{112.11} \\
\hline Significant level & \multicolumn{2}{|r|}{$<0.001$} \\
\hline $\mathrm{N}$ & \multicolumn{2}{|r|}{422} \\
\hline Pseudo $\mathrm{R}^{2}$ & \multicolumn{2}{|r|}{0.16} \\
\hline
\end{tabular}

*, **, *** Significant at 10, 5 and 1 percent probability level respectively

Standard deviations are within the parenthesis 
It is a fact that the estate households must have national identity cards if they want to travel away from estate either internally or internationally. As the migration networks play a significant role in shaping the migration decision (Massey, 1987; Massey et al., 1994) an indicator variable, the ethnicity dummy, was used for migration network in this study. Here, the ethnicity of the household head (being a Tamil person) was considered as the indicator. According to the results, this variable is not a significant factor in determining migration and receiving remittances. Therefore, it should be indicated why such an outcome is possible. Most of the households in estates belong to Tamil ethnicity. A very few people belong to Sinhala and Muslim communities could be found in estates. Therefore, variability in ethnicities is very less. As a result of this, this variable is not a significant factor in migration and receiving remittances.

Ownership of livestock, agricultural land and durable goods were used as a predictors indicating the wealth of the households. Apart from this, the housing structure was also used as predictor to represent the wealth of the family. The results show that the sign of the coefficient for the percentage ownership of durable goods is positive. Therefore, one can assume that the estate households may have used the remittances in buying these durable goods. As the data is for one year only we cannot compare the effects before and after migration. On the other hand, one can argue that these households may be rich in comparison to other households in the estates. Therefore, they tend more to migrate internationally though in most cases it is temporary for a few years. The literature also highlights the fact that sending and receiving remittances depend on the wealth of the family (Barham and Boucher, 1998).

In contrast, Agarwal and Horowitz (2002) show that households' wealth is an important negative determinant of altruistic behaviour of migrants and they further indicate that household wealth does not affect the level of remittances sent by the migrants. The theory of self-interest also supports the fact that remittances increase with the household's assets and income, and migrant's wealth and income as a migrant sends remittances with the aspiration to inherit, to demonstrate creditable behaviour as an investment for the future or with the intent to return home (Hagen-Zanker and Siegel, 2007).

Most of the estate households are supposed to receive employment opportunities from within the estates due to the way the estate sector was established by the British pioneers. Although migration has become a trend among the youth in estates in most cases, the estate officials are responsible for providing work at estates for every working-age household member in the estate. Thus, they work in estates if they do not migrate. Therefore, the sign for the number of workers in the households is negative indicating that propensity to migrate and receiving remittances from both the types of migrants is reduced with increasing numbers of workers in the household.

\section{Household income estimates}

Table 3 shows the results of the household income estimates for migrant households excluding remittances. It highlights that the selection terms are statistically insignificant suggesting that subsample of households receiving remittances are randomly selected from the population. Therefore, the results suggest that income equations can consistently be estimated by OLS as the bias resulting from this would be small.

Although household that receives remittances and households that do not receive remittances are not systematically different (inverse mills ratios are not significant), the results further 
reveal that human capital variables (education) are important determinants of income (expenditure) of households receiving international remittances.

Table 3. Household Income Estimates (Selection Corrected)

\begin{tabular}{|c|c|c|c|c|}
\hline \multirow{2}{*}{ Variable } & \multicolumn{2}{|c|}{$\begin{array}{c}\text { Receive Internal } \\
\text { Remittances }\end{array}$} & \multicolumn{2}{|c|}{$\begin{array}{c}\text { Receive International } \\
\text { Remittance }\end{array}$} \\
\hline & OLS & $\begin{array}{l}\text { Selection } \\
\text { corrected }\end{array}$ & OLS & $\begin{array}{l}\text { Selection } \\
\text { corrected }\end{array}$ \\
\hline Age of household & $\begin{array}{c}-7.15 \\
(-0.36) \\
\end{array}$ & $\begin{array}{c}-7.95 \\
(-0.37) \\
\end{array}$ & $\begin{array}{c}-2.21 \\
(-0.14) \\
\end{array}$ & $\begin{array}{l}-13.05 \\
(-0.55) \\
\end{array}$ \\
\hline Household Size & $\begin{array}{c}-674.51 * * * \\
(-3.56) \\
\end{array}$ & $\begin{array}{c}-754.73^{* *} \\
(-2.97) \\
\end{array}$ & $\begin{array}{c}-800.12^{* *} \\
(-2.55) \\
\end{array}$ & $\begin{array}{c}-729.52 * \\
(-2.09) \\
\end{array}$ \\
\hline $\begin{array}{l}\text { Number of Males } \\
\text { over age } 15\end{array}$ & $\begin{array}{c}788.66^{*} \\
(1.67)\end{array}$ & $\begin{array}{l}607.73 \\
(1.05)\end{array}$ & $\begin{array}{l}-405.46 \\
(-1.07)\end{array}$ & $\begin{array}{l}-518.19 \\
(-0.68)\end{array}$ \\
\hline $\begin{array}{l}\text { Number of Females } \\
\text { over age } 15\end{array}$ & $\begin{array}{l}288.84 \\
(0.56)\end{array}$ & $\begin{array}{l}427.19 \\
(0.63)\end{array}$ & $\begin{array}{l}-419.48 \\
(-1.20)\end{array}$ & $\begin{array}{l}-929.59 \\
(-1.52) \\
\end{array}$ \\
\hline $\begin{array}{l}\text { Ethnicity of the } \\
\text { Household Head }\end{array}$ & $\begin{array}{c}-833.11 \\
(-0.87) \\
\end{array}$ & $\begin{array}{l}-679.43 \\
(-0.65)\end{array}$ & $\begin{array}{l}118.08 \\
(0.22)\end{array}$ & $\begin{array}{l}267.35 \\
(0.41) \\
\end{array}$ \\
\hline $\begin{array}{l}\text { Number of Members } \\
\text { over age } 15 \text { with } 12 \\
\text { years and above } \\
\text { Education }\end{array}$ & $\begin{array}{c}-189.16 \\
(-0.53)\end{array}$ & $\begin{array}{c}-115.86 \\
(-0.30)\end{array}$ & $\begin{array}{l}-394.85 \\
(-0.52)\end{array}$ & $\begin{array}{c}-474.33 \\
(-0.53)\end{array}$ \\
\hline $\begin{array}{l}\text { Number of Members } \\
\text { over age } 15 \text { with } 6 \text { - } \\
11 \text { years of Education }\end{array}$ & $\begin{array}{l}-31.39 \\
(-0.07)\end{array}$ & $\begin{array}{l}66.08 \\
(0.14)\end{array}$ & $\begin{array}{l}1561.17^{* * *} \\
\quad(3.53)\end{array}$ & $\begin{array}{c}1883.36 * * \\
(2.59)\end{array}$ \\
\hline $\begin{array}{l}\text { Number of Members } \\
\text { over age } 15 \text { with } 0-5 \\
\text { years of Education }\end{array}$ & $\begin{array}{c}-318.94 \\
(-0.69)\end{array}$ & $\begin{array}{l}-221.26 \\
(-0.37)\end{array}$ & $\begin{array}{l}1871.17 * * * \\
(3.73)\end{array}$ & $\begin{array}{c}2230.86 * * \\
\quad(2.54)\end{array}$ \\
\hline mills1 & - & $\begin{array}{l}86.67 \\
(0.23) \\
\end{array}$ & - & $\begin{array}{l}-43.63 \\
(-0.23) \\
\end{array}$ \\
\hline mills2 & - & $\begin{array}{l}-53.26 \\
(-0.22)\end{array}$ & - & $\begin{array}{c}3.14 \\
(0.02)\end{array}$ \\
\hline mills3 & - & $\begin{array}{l}33.45 \\
(0.26) \\
\end{array}$ & - & $\begin{array}{c}-173.39 \\
(-0.85) \\
\end{array}$ \\
\hline Constant & $\begin{array}{c}7330.73^{* * *} \\
(6.54) \\
\end{array}$ & $\begin{array}{c}7486.59 * * \\
(2.33)\end{array}$ & $\begin{array}{c}3455.81^{* * *} \\
(3.38) \\
\end{array}$ & $\begin{array}{c}2338.86 \\
(1.09) \\
\end{array}$ \\
\hline Overall Significance & 0.0006 & 0.0001 & 0.0215 & 0.0057 \\
\hline R-squared & 0.25 & .25 & .33 & .36 \\
\hline $\mathrm{N}$ & 93 & 93 & 43 & 43 \\
\hline
\end{tabular}

*, **, *** Significant at 10, 5 and 1 percent probability level respectively

\section{Estimation of income functions for no migration/ remittance counterfactual}

In developing the counterfactual of what household income (expenditure) would have been in the absence of migration and remittances, the following strategy was adopted. First, parameters predicting per capita household expenditures (excluding remittances) were estimated from 286 households that do not receive remittances. The estimated parameters were then applied to 93 
internal migrant households to predict their per capita expenditure in the absence of migration and remittances. The same procedure was adopted in predicting the per capita expenditure of 43 international migrant households. To find the per-capita expenditure excluding remittances, the following regression function was estimated by OLS. The major reason to estimate the function using OLS is that the household receiving households are not systematically different from households receiving no remittances (Table 3).

$$
\begin{aligned}
& P C E X P=\alpha+\beta_{1} H H S Z+\beta_{2} E D U 12 \_A B V+\beta_{3} E D U 6 \_11+\beta_{4} E D U 1 \_5+\beta_{5} \text { CHILD6 } \\
& +\beta_{6} \text { YNGDPNDT }+\beta_{7} \text { OLDDPNDT }+\beta_{8} \text { EDUHHH }+\beta_{9} \text { MALES15 } \\
& +\beta_{10} \text { FEMALES15 }+\beta_{11} \text { GNDRHHH }+\beta_{12} \text { AGEHHH }+\beta_{13} \text { ETHNCTY } \\
& +\beta_{14} \text { LIVSTOK }+\beta_{15} \text { AGRI }+\beta_{16} \text { HOUSING }+\delta_{i} \sum_{i=1}^{4} \text { REGION }_{i}
\end{aligned}
$$

Apart from the variables defined, four regional dummies are included in the regression function. They are; Region 1 = Western Province, Region 2 = Central Province, Region 3 = Uva Province and Region 4 = Sabaragamuwa Province.

Table 4 reports the estimated parameters of the regression functions. The results reveal that better schooling contributes significantly to increase per capita expenditure of estate households. This is an unexpected outcome. Adams (2006) explained that such an outcome is possible if the returns to education in the local market are rather lower for the lowest level of education. The number of children under the age six positively affects the per capita expenditure of the households that do not receive remittances while an increase in the number of young dependents reduces the per capita expenditure of the households that do not receive remittances. The education level of the household head is positively associated with the expenditure. In estimating the regression equation, the gender of the household head also was used as a predictor for per capita expenditure. Results indicate that household heads being males increases the per capita expenditure of the households. On the other hand, living in line rooms reduces the per capita expenditure of estate households significantly.

Having predicted the household per capita expenditure, the estimated values were then used to determine the impact of remittances on poverty and inequality in the estate sector of Sri Lanka. In predicting the per capita expenditure including remittances, migrant home earnings are first set to zero and the total household expenditure was calculated. The remittances sent by the internal and international migrant were then added to the total predicted expenditure and per capita expenditure including remittances was calculated finally. The two types of income distributions (excluding remittances and including remittances) were then used to determine the impact of remittances on poverty and inequality in the estate sector of Sri Lanka. Several scenarios were considered in estimating the impact. They are,

1. Based on the receipt of remittances without distinguishing between internal and international remittances for all households (remittances receiving vs. no remittances receiving)

2. Based on the receipt of remittances considering three types of households (no remittances receiving, internal remittances receiving and international remittances receiving) separately

3. Based on the receipt of remittances considering internal and international remittances separately for all households 
Table 4. Results of Regression for Generating Counterfactual Income - OLS Estimates

\begin{tabular}{|c|c|c|}
\hline Variable & $\begin{array}{l}\text { Regression } \\
\text { Coefficient }\end{array}$ & t-ratio \\
\hline Age of Household Head in years & -50.69 & -1.52 \\
\hline Gender Household Head & $1228.84 * *$ & 2.12 \\
\hline Educational Level of Household Head in years & $85.23^{*}$ & 1.84 \\
\hline Household Size & -246.48 & -0.61 \\
\hline Number of Males over age 15 & 324.44 & 0.30 \\
\hline Number of Females over age 15 & -243.33 & -0.22 \\
\hline Number of Children under age 6 & $1407.32 *$ & 1.78 \\
\hline Number of Young Dependents & $-748.09 *$ & -1.71 \\
\hline Number of Old Dependents & 200.06 & 0.34 \\
\hline $\begin{array}{l}\text { Number of Members over age } 15 \text { with } 12 \\
\text { years and above Education }\end{array}$ & $2308.89 * *$ & 2.04 \\
\hline $\begin{array}{l}\text { Number of Members over age } 15 \text { with 6- } 11 \\
\text { years of Education }\end{array}$ & -512.24 & -0.47 \\
\hline $\begin{array}{l}\text { Number of Members over age } 15 \text { with 1-5 } \\
\text { years of Education }\end{array}$ & -801.98 & -0.74 \\
\hline Ethnicity of the Household Head & -299.21 & -0.35 \\
\hline Livestock Owner & -351.71 & -1.03 \\
\hline Agricultural Land Owner & 431.26 & 1.11 \\
\hline Housing Structure & $-1739.21^{* * *}$ & -3.23 \\
\hline Region 1 & 553.36 & 0.72 \\
\hline Region 2 & 904.44 & 1.48 \\
\hline Region 3 & 1653.14 & 1.39 \\
\hline Region 4 & $1417.22 *$ & 1.79 \\
\hline Constant & $9588.00 * * *$ & 4.70 \\
\hline Overall Significance & \multicolumn{2}{|c|}{0.0000} \\
\hline R-squared & \multicolumn{2}{|c|}{0.41} \\
\hline $\mathrm{N}$ & \multicolumn{2}{|c|}{286} \\
\hline
\end{tabular}

*, **, *** Significant at 10, 5 and 1 percent probability level respectively

Table 5 shows the calculated Foster Greer Thorbecke (FGT) indices based on the receipt of remittances without distinguishing between internal and international remittances for all households. According to the results, Head Count Index (HCI) decreases by $0.71 \%$ Poverty Gap Index (PGI) decrease by $0.4 \%$ and Squared Poverty Gap Index (SPGI) reduces by $0.18 \%$ when remittances are included in the household expenditure. As far as income inequality is concerned, it is the same when remittances are included in the household income distribution (Table 5). 
Table 5. Estimates of FGT Indices - Remittances Receiving and No Remittance Receiving Households

\begin{tabular}{lcc}
\hline & Excluding Remittances & Including Remittances \\
\hline HCI & 5.68 & 4.97 \\
PGI & 1.95 & 1.55 \\
SPGI & 0.98 & 0.79 \\
GINI & 0.21 & 0.21 \\
\hline
\end{tabular}

Poverty line equals to Rs. 3028.00 for the survey period of 2009/2010

The average income of households in no remittance scenario is somewhat lower than that of households that receive remittances. Therefore, income excluding remittance scenario would be to the left of that of including remittance scenario. The reason that could be highlighted in this regard is that most of the positive impacts of remittances on poverty come from increases in household income, rather than any changes in the level of income distribution in a country.

Table 6 shows HCI, PGI, and SPGI of three types of households based on the receipt of Remittances. It reveals that international remittances have fairly higher HCI reduction than that of internal remittances while income inequality is getting slightly decreased due to internal and international remittances in comparison to excluding remittances situation.

Table 6. Estimates of FGT Indices - No remittance receiving households, Internal Remittance Receiving and International Remittance Receiving

\begin{tabular}{lccccc}
\hline & \multirow{2}{*}{ No Remittance } & \multicolumn{2}{c}{ Internal Migration } & \multicolumn{2}{c}{ International Migration } \\
\cline { 3 - 6 } & & $\begin{array}{c}\text { Excluding } \\
\text { Remittances }\end{array}$ & $\begin{array}{c}\text { Including } \\
\text { Remittances }\end{array}$ & $\begin{array}{c}\text { Excluding } \\
\text { Remittances }\end{array}$ & $\begin{array}{c}\text { Including } \\
\text { Remittances }\end{array}$ \\
\hline HCI & 4.19 & 9.67 & 7.53 & 6.97 & 4.65 \\
PGI & 1.58 & 2.69 & 1.33 & 2.86 & 1.88 \\
SPGI & 0.94 & 0.96 & 0.33 & 1.26 & 0.78 \\
GINI & 0.21 & 0.22 & 0.20 & 0.23 & 0.22 \\
\hline
\end{tabular}

Poverty line equals to Rs. 3028.00 for the survey period of 2009/2010

Figure 1 shows that in the presence of remittances, the average income of households is slightly greater than that of the households that do not receive remittances. It is also evident from the graph that, if the international remittances are included in their income, per capita expenditure is higher and the income distribution would be skewed to the right of that of excluding remittance situation. Income inequality also slightly reduces. 


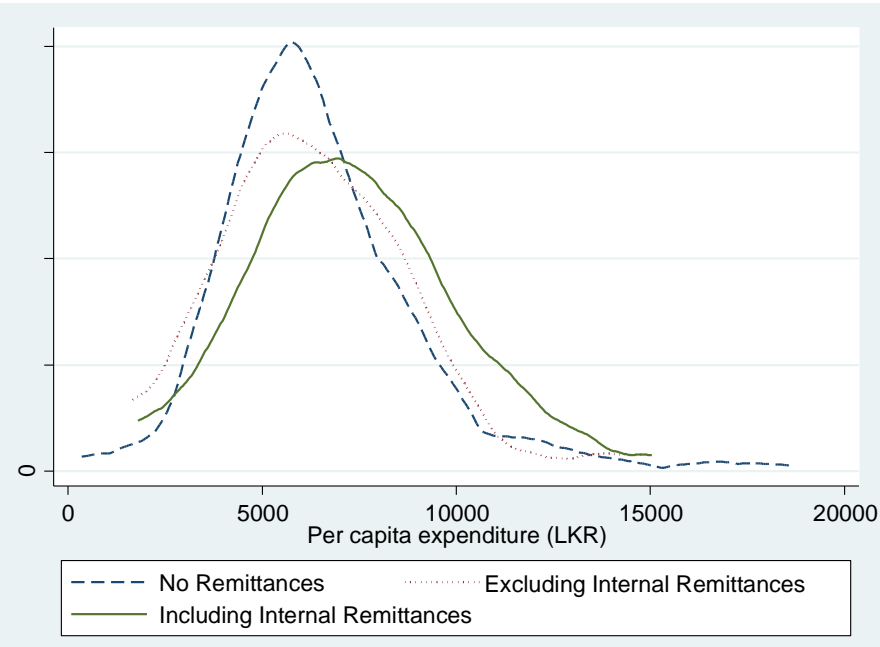

Figure 1. Kernel Density Plots of Per Capita Expenditure of Households in three Scenarios; No remittances, Excluding Internal Remittances and Including Internal Remittances

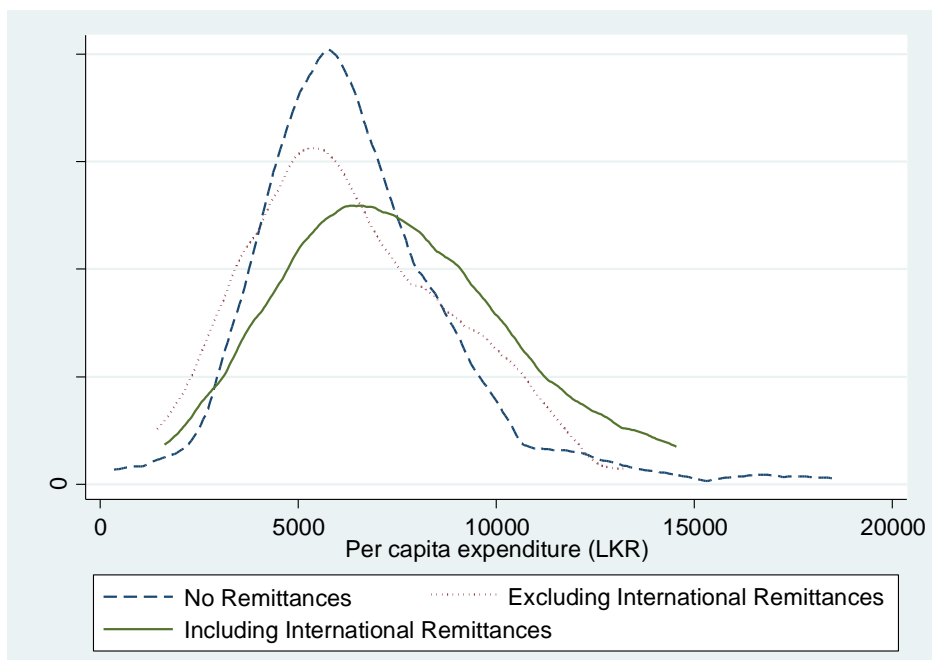

Figure 2. Kernel Density Plots of Per Capita Expenditure of Households in Three Scenarios; No remittances, Excluding International Remittances and Including International Remittances

The column two of Table 7 presents the poverty measures for all households (422). The first column presents the poverty indices with no remittances. The second column of Table 7 presents the poverty indices including international remittances for all 422 households while column three shows the poverty indices including international remittances for 422 households. The results suggest that all the values of the indices reduce slightly when 
remittances are included in the household income. However, the income inequality of the household decreases slightly when remittances are included in the household income while income inequality increases slightly when international remittances are included.

Table 7. Estimates of FGT Indices - No remittance receiving households, Internal Remittance Receiving and International Remittance Receiving for all Households

\begin{tabular}{lccc}
\hline & No Remittances & $\begin{array}{c}\text { Including Internal } \\
\text { Remittances }\end{array}$ & $\begin{array}{c}\text { Including International } \\
\text { Remittances }\end{array}$ \\
\hline HCI & 5.68 & 5.21 & 5.45 \\
PGI & 1.96 & 1.65 & 1.86 \\
SPGI & 0.98 & 0.84 & 0.93 \\
GINI & 0.21 & 0.21 & 0.22 \\
\hline
\end{tabular}

\section{CONCLUSIONS}

The results of the econometric estimations and simulations performed in this study clearly show that migration and remittances increase household income and reduce poverty and income inequality of the estate sector of Sri Lanka. Poverty incidences of internal migrant and international migrant households decrease from $9.67 \%$ to $7.53 \%$ and $6.97 \%$ to $4.65 \%$ respectively. The depth of poverty decreases from $2.69 \%$ to $1.33 \%$ while the severity of poverty decreases from $0.96 \%$ to $0.33 \%$ in internal migrant households. Similarly, in the international migrant households, the depth of poverty decreases from and $2.86 \%$ to $1.88 \%$ and the severity of poverty decreases from $1.26 \%$ to $0.78 \%$. Furthermore, results indicate that the households having durable goods receive more international remittances compared to those who possess agricultural lands. This indicates that the international migrants have come from either more abled richer households or they have improved their lifestyles with the receipt of the remittances. This finding suggests that international migration has a potential to widen income distribution in the future despite the favorable effect on income distribution observed. The results also indicate that the propensity to receive remittances from both internal and international migrants are higher in households with well-educated members and migrants. Human capital development in the estate sector is recommended to reap more benefits from migration and remittances.

\section{REFERENCES}

Adams, R.H. (1989). Worker Remittances and Inequality in Rural Egypt, Economic Development and Cultural Change. 38 (1), 45-71.

Adams, R.H. (2006). Remittances, Poverty, and Investment in Guatemala. In Ozden, C. and Schiff, M. (Eds.), International Migration, Remittances, and the Brain Drain, pp 53- 80, Co publication of the World Bank and Palgrave Macmillan, Washington, D.C.

ADB (Asian Development Bank) (2011). Sri Lanka Poverty Assessment Background Paper for the Country Partnership Strategy 2012 - 2016, Asian Development Bank Colombo, Sri Lanka 
Anon. (2018). Statistical abstract. Department of Census and Statistics, Colombo.

Agarwal, R. and Horowitz, A.W. (2002). Are International Remittances Altruism or Insurance? Evidence from Guyana Using Multiple-Migrant Households, World Development. 30, 2033-44.

Arunatilake, N., Jayaratne, S., Jayawardena, P., Jayaweera, R. and Weerakoon, D. (2010). Impact of Remittances on The Household of The Emigrant and on The Economy of The Migrant's Country: Sri Lanka. Project report submitted on $10^{\text {th }}$ Round Regional Research Competition of South Asia Network of Economic Research Institutes.

Barham,B. and Boucher, S. (1998). Migration, Remittances, and Inequality: Estimating the Effects of Migration on Income Distribution, J. Development Economics. 55(2), 307-331.

Dharmadasa, R.A.P.I.S. (2011). The Impact of Labour Migration on Labor Productivity in Tea Plantation Sector: A Case Study in Badulla District, M.Sc. Thesis, Department of Agricultural Economics and Extension, Faculty of Agriculture, University of Ruhuna, Sri Lanka.

Hagen-Zanker, J. and Siegel, M. (2007). The Determinants of Remittances: A Review of the Literature, Working Paper, MGSoG/2007/WP003, Maastricht Graduate School of Governance Maastricht University, The Netherlands.

Karunaratne, H.D. (2008). International Labour Migration, Remittances and Income Inequality in a Developing Country: The Case of Sri Lanka. Keizai-Shirin: Hosei Economic Review. 15(3), 179-220.

Larson, D. and Mundlak, Y. (1997). On the Inter-Sectoral Migration of Agricultural Labor, Economic Development and Cultural Change. 45(2), 259 - 319.

Lewin, P.A., Fisher, F. and Weber, B. (2012). Do Rainfall Conditions Push or Pull Rural Migrants: Evidence from Malawi, Agricultural Economics. 43, 191-204.

Massey, D.S. (1987). Understanding Mexican Migration to the United States, American Journal of Sociology. 92(6), 1372-1403.

Massey, D.S., Goldring, L.P. and Durand, J. (1994). Continuities in Transnational Migration: An analysis of 19 Mexican Communities, American Journal of Sociology. 99, 1492-1533.

Matsumoto, T., Kijima, Y. and Yamano, T. (2006). The Role of Local Nonfarm Activities and Migration in Reducing Poverty: Evidence from Ethiopia, Kenya, and Uganda, Agricultural Economics. 35, 449-458.

Mora, J. and Taylor, J.E. (2006). Determinants of Migration, Destination, and Sector Choice: Disentangling Individual, Household, and Community Effects, pp 21-52. In: Ozden, C. and Schiff, M. (eds.), International Migration, Remittances and the Brain Drain. The World Bank/ Palgrave Macmillan, Washington, D.C.

Mendola,M. (2012). Rural Out-Migration and Economic Development at Origin. What Do We Know? Journal of International Development. 24(1), 102-122. 
Mendola, M. (2005). Migration and Technological Change in Rural Households: Complements or Substitutes? Department of Economics Working Paper, No. 15, University of Milan

Perera., S.(2005). Patterns, Determinants and Consequences of Internal Migration in Sri Lanka 1981-2001. IWE Journal. 5, 76-101.

Portes, L.S.V. (2009). Remittances, Poverty and Inequality, Journal of Economic Development. 34(1), $127-140$.

Ratha, D. (2003). Workers' Remittances: An Important and Stable Source of External Development Finance. pp. 157-175. In: Global Development Finance, The World Bank. Washington, DC.

Shaw, J. (2008). Migrants Remittances and Low Income Households in Sri Lanka: Development Policy Issues, Working Paper No.09, Monash Asia Institute, Clayton

World Bank (2007). Sri Lanka Poverty Assessment: Engendering Growth with Equity: Opportunities and Challenges, World Bank, Washington D.C.

World Bank (2015). Tajikistan: Slowing Growth, Rising Uncertainties, Tajikistan Economic Update No. 1, World Bank Group on Macroeconomics \& Fiscal Management Global Practice, Tajikistan

Wu, Z. (2008). Self-Selection and Earnings of Migrants: Evidence from Rural China, Osaka School of International Public Policy, Discussion Paper No. 08-25.

Yang, D. (2011). Migrant Remittances, Journal of Economic Perspectives. 25(3), 129-152. 